\title{
UNCAC and Civil Society Activism Against Corruption In Bangladesh
}

\author{
Sumaiya Khair ${ }^{1}$
}

\section{INTRODUCTION}

Corruption is a phenomenon that knows no social or cultural bounds and which occurs more or less in all societies and countries irrespective of their legal, socio-cultural, political and economic dynamics. ${ }^{2}$ Notwithstanding, corruption is believed to predominate in contexts where public officials enjoy unfettered discretion, where governmental activities lack accountability and transparency and where the private sector and civil society institutions are weak and ineffective. ${ }^{3}$ Given the diversity of the problem in terms of causes, forms and impacts, there is no single universally agreed on definition of corruption. ${ }^{4}$ It is widely accepted that corruption undermines key elements of good governance that is, transparency, accountability, rule of law, participation, ${ }^{5}$ and integrity, and reinforces injustice, discrimina-

1 Of the Board of Editors; Ph.D. (University of East London); Professor of Faculty of Law, University of Dhaka.

2 The Context, Transparency International Bangladesh, https://www.tibangladesh.org/beta3/index.php/ en/about-us/the-context.

3 Alan Doig \& Stephen Riley, Corruption and Anti-Corruption Strategies: Issues and Case Studies from Developing Countries, in Corruption \& InTEgrity Improvement Initiatives in Developing Countries 45, 49 (Sahr John Kpundeh \& Irène Hors eds., 1998).

4 Ministry of Foreign Affairs of Fin., Anti-Corruption Handbook for Development Practitioners 19 (2012); see also Berihun Adugna Gebeye, Corruption and Human Rights: Exploring the Relationships 5 (Univ. of Denver, Working Paper No. 70, 2012), http://www.du.edu/korbel/hrhw/ workingpapers/2012/70-gebeye-2012.pdf.

5 See United Nations Econ. \& Soc. Comm'n for Asia \& the Pac., What is Good GovernAncE?, (2009), http://www.unescap.org/sites/default/files/good- 
tion, exclusion, and poverty. Accordingly, "[c] ombating corruption is not an end in itself" - rather it is "part of the broader goal of creating more effective, fair and efficient government," which is why "[r] eformers are not just concerned with countering corruption per se but with reversing its negative impact on development and society as a whole."6

Indeed, the range of anti-corruption instruments and conventions ${ }^{7}$ is a reflection of the significance that has been attached to fighting corruption worldwide. Amongst them, the United Nations Convention Against Corruption (UNCAC) "represents a[] [strong] attempt to establish universal anticorruption standards, including a common set of obligations on the part of countries around the world to cooperate in investigations and enforcement." 8 The UNCAC breaks new ground by stressing on state obligation "to promote multi-sectoral institutional, legal and policy reforms at ... [the] ... national level, as well as" participation of society, as fundamental "to creating a strong and sustainable basis for controlling

governance.pdf.

6 Jeremy Pope, Ti Source Book 2000: Confronting Corruption: The Elements of A National Integrity System, at xviii (2000).

7 Landmark instruments include Foreign Corrupt Practices Act of 1977 (FCPA), 15 U.S.C. $\$ \$ 78 \mathrm{dd}-1,78 \mathrm{dd}-2,78 \mathrm{~m}, 78 \mathrm{ff}$ (1977); Inter-American Convention against Corruption, Mar. 29, 1996, 35 I.L.M. 724; OECD Convention on Combating Bribery of Foreign Public Officials in International Business Transactions, Dec. 17, 1997, 37 I.L.M. 1; Criminal Law Convention on Corruption, opened for signature Jan. 27, 1999, C.E.T.S. No. 173; Civil Law Convention on Corruption, opened for signature Nov. 4, 1999, C.E.T.S. No. 174; The United Nations Convention against Transnational Organised Crime, Nov. 15, 2000, 2225 U.N.T.S. 209; The African Union Convention on Preventing and Combating Corruption, July 1, 2003, 43 I.L.M. 5; The United Nations Convention Against Corruption, opened for signature Dec. 9, 2003, 2349 U.N.T.S. 41.

8 Lucinda A. Low, The United Nations Convention Against Corruption: The Globalization of Anticorruption Standards 2-3 (2006) (paper presented at the International Bar Association (IBA), International Chamber of Commerce (ICC), Organization for Economic Cooperation and Development (OECD) conference on "The Awakening Giant of Anticorruption Enforcement" (London, May 4-5, 2006)), http://www.steptoe.com/ assets/attachments/2599.pdf. 
corruption." "While many assume, albeit incorrectly, "that traditional or classical international law . . . [is] merely state-to-state and that . . individuals and ... other nonstate actors [do] not have rights or duties based directly on international agreements or customary international law," there are "vast numbers of formally recognized actors in the international legal process other than the state." ${ }^{10}$ Civil society is essentially one such nonstate actor that works with, among other things, human rights and good governance, nationally and internationally, by dint of their experience in grassroots organisation, strong advocacy, and active lobbying for reforms in law and policy.

Against the backdrop of a troubled political history, inconsistent anti-corruption efforts, and the gap between political rhetoric and actual policies, Bangladesh has witnessed the rise of non-state actors in the fight against corruption as early as the mid-1990s, prior to the advent of the UNCAC. A key feature of the anti-corruption experience in Bangladesh has been the plurality of non-state drivers, pushing for law and policy reforms and demanding public sector accountability in decision-making processes. The civil society in Bangladesh broadly comprising of NGOs, media, academia, think tanks, citizen's groups, etc., has progressively led discussions and assessments of, inter alia, key governance issues of human rights, rule of law, and corruption. Engaged in challenging the top-down and state controlled close structures, the civil society has been vocal in demanding government accountability through transparency, participation, and democratic governance.

While government responsiveness to demands of the civil society and receptiveness of their recommendations was limited at the beginning, in the face of ineffective anti-corruption institutions, the role and function of the civil society in furthering public interest in good governance and corruption have gradually gained legitimacy. This paper showcases the

Iftekharuzzaman, The UN Convention Against Corruption: Implications for BANgladesh - What NeXt? 3 (2007) (paper presented at the seminar organized jointly by the Anti-Corruption Commission (ACC) and Transparency International Bangladesh (TIB) (Dhaka, Dec. 9, 2007)), http://www.ti-bangladesh. org/oldweb/Documents/UNCAC-IACD07.pdf.

10 Jordan J. Paust, Non-State Actor Participation in International Law and the Pretense of Exclusion, 51 Virginia Journal of International Law 977, 977 (2011). 
work of Transparency International Bangladesh (TIB), accredited chapter of Berlin-based Transparency International, which has established itself as an independent, non-profit and non-partisan NGO with a mission to "catalyze and strengthen a participatory social movement to promote and develop institutions, laws and practices for combating corruption in Bangladesh, and to establish an efficient and transparent system of governance, politics and business." addressing both the demand and supply sides of corruption in Bangladesh by engaging both the government and the public on an issue that is, at the same time, considered sensitive and a way of life. It has been instrumental in placing corruption on the political agenda and pushing for institutional reforms on the one hand and helping citizens raise their voice against the practice on the other.

This paper will first examine the core provisions of the UNCAC, the political environment of Bangladesh, conceptual issues related to good governance, corruption, human rights and civil society, and highlight how Bangladesh acceded to the UNCAC and the transformative moves it has taken thereafter pursuant to treaty obligations; then it will describe the role of TIB in the fight against corruption and illustrate its good practices.

\section{THE UNCAC IN BRIEF}

Corruption was a key focus in both the United Nations Declaration Against Corruption and Bribery in International Commercial Transactions 1996 and the United Nations Convention Against Transnational Organized Crime 2003. ${ }^{12}$ Recognising the necessity of having in place an anti-corruption convention that is "universal, binding, effective and efficient" but at the same time sufficiently flexible "to take into account the legal, social, cultural, economic and political differences [among] member countries," the United Nations (UN) established an Ad-Hoc Committee in December 2000 for negotiation of the convention..$^{13}$ After two years of negotiations,

11 See Vision \& Mission, Transparency International Bangladesh, https:// www.ti-bangladesh.org/beta3/index.php/en/about-us/vision-mission (emphasis added).

12 IftekharUzzaman, supra note 9, at 2.

13 Id. 
the General Assembly adopted the UNCAC on 31 October 2003. ${ }^{14}$ As of 1 December 2015, the total number of countries that have ratified the UNCAC stood at 178 while the number of signatories amounted to $140 .^{15}$

The first global legally binding and comprehensive instrument on corruption, the purpose of UNCAC as stated in Article 1 is to "a) promote and strengthen measures to prevent and combat corruption more efficiently and effectively; b) promote, facilitate and support international cooperation and technical assistance in the prevention of and fight against corruption, including asset recovery; and c) promote integrity, accountability and proper management of public affairs and public property." ${ }^{16}$ It "obliges the States Parties to implement a wide and detailed range of anti-corruption measures through their laws, institutions and practices." 17

Interestingly, the UNCAC does not explicitly define corruption but instead refers to specific acts that amount to corruption which include bribery, embezzlement, money laundering, concealment and obstruction of justice. ${ }^{18}$ Given the diversity of corruption in terms of acts and contexts, the UNCAC provides a combination of optional and mandatory provisions to enable States Parties to make informed decisions in choosing implementation options. ${ }^{19}$ Most of the provisions in the UNCAC allude to working within the principles of a State's domestic law, which essentially

$14 \quad I d$.

15 See United Nations Convention Against Corruption Signature and Ratification Status as of 12 December 2016, United Nations Office on Drugs and Crime, https://www.unodc.org/unodc/en/treaties/CAC/ signatories.html.

16 United Nations Convention Against Corruption art. 1, opened for signature Dec. 9, 2003, 2349 U.N.T.S. 41 (entered into force Dec. 14, 2005) [hereinafter UNCAC].

17 Transparency Int'l, UN Convention Against Corruption (UnCAC) SUMmARY, http://www.multaqa. org/pdfs/UNCACSummary.pdf.

18 Hannes Hechler, UNCAC in a Nutshell - A Quick Guide to the United Nations Convention Against Corruption for Embassy and Donor Agency Staff, U4 BRIEF, Sept. 2010, at 1, http://www.cmi.no/publications/file/3769-uncac-in-a-nutshell. pdf.

19 Id. 
allows significant flexibility in interpreting the UNCAC's requirements in the context of any given country. ${ }^{20}$

The UNCAC focuses on five broad parameters, namely preventive measures (Chapter II), criminalisation and law enforcement (Chapter III), international cooperation (Chapter IV), asset recovery (Chapter V) and technical assistance and information exchange (Chapter VI).

\section{a. Preventive Measures (Articles 5-14)}

The UNCAC attaches the same importance to corruption prevention as to control and sanctions and prescribes "interlinked and mutually reinforcing" measures for both the public and private sectors. With regard to the public sector, among other things, it calls for the establishment of independent and adequately resourced anti-corruption bodies and enhanced transparency in political finance. ${ }^{21}$ States Parties must "ensure that their public services are subject to safeguards that promote efficiency, transparency and recruitment based on merit." 22 "[P]ublic servants should be subject to codes of conduct, requirements for financial and other disclosures, and appropriate disciplinary measures. Transparency and accountability in matters of public finance must ... be promoted, and specific requirements are established for the prevention of corruption," particularly in high risk activities, such as "the judiciary and public procurement." ${ }^{23}$ With regard to the private sector, the UNCAC enjoins upon States Parties to take measures to strengthen accounting and auditing standards and introduce sanctions for non-compliance. ${ }^{24}$ It recommends codes of conduct, disclosure policies, and comprehensive regulatory regime to detect and prevent money laundering. Concerted efforts of all stakeholders are fundamental to effective implementation of corruption prevention measures. Accordingly, the UNCAC calls on States Parties to ensure civil society participation in anti-corruption initiatives and decision-making processes, provide public

$20 \quad$ Id. at 6.

21 Press Release, Consensus Reached on UN Convention Against Corruption, U.N. Press Release SOC/CP/270 (Oct. 2, 2003).

22 Id.

23 Id.

24 UNCAC, supra note 16, art. 12. 
access to information and create channels to report corruption, including protection for whistleblowers. ${ }^{25}$

\section{b. Criminalisation and Law Enforcement (Articles 15-42)}

The UNCAC requires States Parties to recognise as criminal offences not only corrupt acts, such as bribery and the embezzlement of public funds, if they are not so already under their domestic laws, but also the obstruction of justice, trading in influence, abuse of functions, illicit enrichment and the concealment and laundering of the proceeds of corruption. ${ }^{26}$ The UNCAC goes a step further and criminalises private-to-private bribery and embezzlement, and bribery of foreign public officials and officials of public international organisations. ${ }^{27}$

\section{c. International Cooperation (Articles 43-50)}

The UNCAC explicitly states, "where appropriate and consistent with their domestic legal system, States Parties shall consider assisting each other in investigations of and proceedings in civil and administrative matters relating to corruption" (Article 43). ${ }^{28}$ The UNCAC obliges them "to render ... mutual legal assistance in terms of gathering and transferring evidence for use in court" and extradition of offenders. States Parties "are also required to undertake measures which will support the tracing, freezing, seizure and confiscation of the proceeds of corruption." ${ }^{29}$ States may not refuse

$25 \quad$ Id. art. 13.

26 Id. arts. 15-25.

27 Id. arts. 21-23.

28 Id. art. 44.

29 United Nations Convention Against Corruption: Convention Highlights, United Nations Office on Drugs and Crime, http://www.unodc.org/unodc/en/treaties/ CAC/convention-highlights.html\#International_cooperation. 
assistance on the basis of bank secrecy and can involve dual criminality requirements only in limited cases. ${ }^{30}$

\section{d. Asset Recovery (Articles 51-59)}

Consensus on the mechanisms to be used for asset recovery was reached after intense negotiations. ${ }^{31}$ This issue is particularly significant "for many developing countries where high-level corruption has plundered the national wealth, and where resources are badly needed for reconstruction and the rehabilitation of societies under new governments." 32 UNCAC provisions on international cooperation have a direct bearing on asset recovery processes. ${ }^{33}$ Such cooperation may be rendered in different ways, for example:

[I]n the case of embezzlement of public funds, the confiscated property would be returned to the state requesting it; in the case of proceeds of any other offence covered by the [UNCAC], the property would be returned providing the proof of ownership or recognition of the damage caused to a requesting state; in all other cases, priority consideration would be given to the return of confiscated property to the requesting state, to the return of such property to the prior legitimate owners or to compensation of the victims. ${ }^{34}$

\section{e. Technical Assistance and Information Exchange (Articles 60-62)}

The UNCAC recommends States Parties to "initiate, develop or improve specific training programmes for its personnel responsible for preventing and combating corruption." 35 Such initiatives may include, but are not limited to:

[E]ffective measures to prevent, detect, investigate, punish and control corruption, including the use of evidence-gathering and investigative methods; building capacity in the development and planning of strategic anticorruption policy; training competent authorities in the preparation

30 Transparency Int'L, supra note 17, at 3.

31 United Nations Convention Against Corruption: Convention Highlights, supra note 29.

32 Id.

33 Id.

34 Id.

35 UNCAC, supra note 16, art. 60 
of requests for mutual legal assistance that meet the requirements of this Convention; evaluation and strengthening of institutions, public service management and the management of public finances, including public procurement, and the private sector. ${ }^{36}$

Of particular relevance to the present paper are the UNCAC provisions in Article 13 that call on States Parties to take "appropriate measures" to "promote the active participation of individuals and groups outside the public sector in the prevention of and the fight against corruption" by "enhancing the transparency of and promoting the contribution of the public in decision-making processes, ensuring that the public has effective access to information; [and] respecting, promoting and protecting the freedom to seek, receive, publish and disseminate information concerning corruption." ${ }^{37}$ Additionally, the UNCAC urges States Parties to "develop and implement or maintain effective, coordinated anti-corruption policies that promote the participation of society and reflect the principles of the rule of law, proper management of public affairs and public property, integrity, transparency and accountability" (Article 5) ${ }^{38}$ and to "enhance transparency in [their] public administration including with regard to its organization, functioning and decision making processes, where appropriate" by introducing systems and procedures that would enable the public access necessary information (Article 10). ${ }^{39}$ Article 63 (4)(c) of the UNCAC requires States Parties to "agree upon procedures and methods of work," ${ }^{40}$ including "[cooperation] with relevant international and regional organizations and mechanisms and non-governmental organizations." ${ }^{31}$ Indeed, the fact that the civil society has been included in the UNCAC

$36 \quad I d$.

$37 \quad I d$. art. 13.

38 Id. art. 5.

39 Id. art. 10.

$40 \quad$ Id. art. 63(4)(c).

41 Id. 
review process not only enhances the "credibility and effectiveness of the review process" but also ensures "accountability and transparency." ${ }^{2}$

\section{A. Bangladesh's Accession to the UNCAC: The Country Context}

Since its independence, Bangladesh has arguably been "moving away from what is considered as 'minimalist democracy' (transfer of power through regular, free and contested elections, fundamental freedoms, civilian control over policy and institutions) to an 'illiberal democracy', characterised by misuse of state power for partisan[,] personal gain and politicisation of . . . state institutions." ${ }^{33}$ Dominated by a two-party polity, the political scenario in Bangladesh has become hostage to confrontational politics and a culture in which the winner in elections takes full control over key institutions of the state and public resources and the losers are severely sidelined. ${ }^{44}$ "Political patronage by the major parties has permeated nearly [all key] state institutions in ways that seriously undermine the accountability structures." ${ }^{5}$ "The prevalence of semi-authoritarian, or 'hybrid' regimes where the existence of formal democratic processes, such as elections, masks (often, in part, to legitimise) the reality of authoritarian domination" is believed to undermine good governance. ${ }^{46}$

Bangladesh has seen both parliamentary and presidential forms of government and martial law regimes at different stages of its political history. Following the restoration of parliamentary form of government in 1991, successive parliamentary elections have taken place under a

42 Iftekhar Zaman et al., UN Convention Against Corruption Civil Society ReView: BANGLADESH 2011 (2011).

43 Institute of Governance Studies, BRaC University, The State of Governance in Bangladesh 20o8: Confrontation, Competition, Accountability, at Xv (2009).

$44 \quad I d$. at 2.

45 Manzoor Hasan et al., Background Paper for the 7th Five Year Plan of the Government of Bangladesh: Governance and Justice, Ministry of Planning BANGLAdESH 81 (Feb. 21, 2015), http://www.plancomm.gov.bd/ wp-content/ uploads/2015/02/12_Governance-and-Justice-_Final-Draft.pdf.

46 Carl Gershman, The State of Democratic Governance: Achievements and Challenges in Democracy Rising. Assessing the Global Challenge, in Democracy Rising: Assessing the Global Challenges 37 (Heraldo Muñoz ed., 2006). 
non-party Caretaker Government (CTG) that ensured a "re-emergence of parliamentary democracy" and a peaceful transfer of power. ${ }^{47}$ A unique parliamentary innovation, the idea of a neutral CTG evolved in response to demands for a pragmatic means of changing governments through credible and impartial elections. The 13th amendment to the Bangladesh Constitution, passed on 26 March 1996, provided for the transfer of power to a non-partisan CTG, composed of a Chief Adviser (with status of Prime Minister) and a prescribed number of advisers (with status of ministers) at the end of a parliamentary term. Three CTGs have since held office, and the immediate past amongst them, technically fourth in line ${ }^{48}$ assumed responsibility on 12 January 2007, when the President declared a state of emergency in the wake of violent political agitations. One of the key priorities of this CTG was to root out corruption, given that Bangladesh was ranked at the bottom of the list of countries where corruption was perceived to be the highest for five consecutive years from 2001 to 2005 in the Corruption Perceptions Index (CPI) ${ }^{49}$ Since January 2007, "a new governance paradigm [sic] [emerged in Bangladesh] that sought to strengthen democratic framework of the country in order to ensure that it is free from the scourge of corruption, discrimination and exploitation." 50

During its tenure, the CTG undertook some major institutional reforms which included inter alia the separation of the Judiciary from the Executive, the establishment of the National Human Rights Commission,

47 Transparency Int'l Bangl., National Integrity Systems Country Study RePORT: BANgladesh 9 (2003).

48 The expiry of the BNP rule was followed by a Caretaker Government headed by the President for a brief period of time which dissolved soon after amidst much controversy and speculation.

49 The Corruption Perceptions Index (CPI) is released annually by Transparency International (TI) since 1995. It is a global survey of surveys on governance and corruption related indicators conducted by reputed international organisations. CPI provides international comparison of countries by perceived prevalence of political and administrative corruption. To date no country has yet scored 100 percent indicating that corruption exists in all countries of the world. Corruption clearly remains a global problem. See Transparency International, http:// www.transparency.org.

50 Human Rights Council Res. 5/1, U.N. Doc. A/HRC/WG.6/4/BGD/1, at 2 (Nov. 19, 2008). 
the reconstitution of the Anti-Corruption Commission, the revamping of the Election Commission, the establishment of the Truth and Accountability Commission (TAC) and police and local government reforms. ${ }^{51}$ Legislative developments during the tenure of the CTG took place by way of Presidential Ordinances in the absence of a Parliament and largely in response to long-standing demands of civil society and human rights organisations. The laws passed at this time included: The National Human Rights Commission Ordinance 2007, The Public Procurement Rules 2008, The Truth Commission Ordinance 2008, The Voluntary Disclosure Ordinance 2008, The Government Attorney Services Ordinance 2008, The Anti-Terrorism Ordinance 2008, The Representation of the People (Amendment) Ordinance, 2008 and The Right to Information Ordinance $2008 .^{52}$ One of the noteworthy highlights of the CTG tenure was the accession to the UNCAC in 2007. The Government of Bangladesh prepared the Compliance and Gap Analysis of "the implications of the UNCAC provisions on Bangladesh's legislation, practices and institutional realities, including an assessment of the extent of compliance, gaps and capacity needs" ${ }^{\prime \prime 3}$ and submitted the report to the Conference of the States Parties to the UNCAC in 2008. This initiative was supported by the Institute of Governance Studies (IGS) at BRAC University Bangladesh, the German Technical Cooperation (GTZ) and the Basel Institute on Governance (BIG) in Switzerland. ${ }^{54}$ In 2008, the Ministry of Home Affairs and the Attorney General's Office were nominated by the Government of Bangladesh as the "Central Authorities" for providing "mutual legal assistance (MLA) under UNCAC." ${ }^{55}$ In 2009, the Government of Bangladesh developed an Action Plan for UNCAC Compliance, the "objective of [which] is to establish an operational guidance for relevant institutions to implement UNCAC. The

\footnotetext{
$51 \quad I d$. at 11.

52 Id. at 13-14.

53 Gov't of the People's Republic of Bangl., UnCAC: A Bangladesh Compliance \& Gap Analysis 17 (2d ed. 2008) [hereinafter Compliance \& Gap AnAlysis].

54 Gov't of the People's Republic of Bangl., UnCAC: A Bangladesh Action Plan for Compliance (2009).

55 Compliance \& Gap Analysis, supra note 53, at 14.
} 
Plan is expected to fulfil Bangladesh's commitment to comply with UNCAC and provides a framework for monitoring of progress." 56

While the arrest and trial of celebrated politicians for corruption demonstrated the CTG's commitment to crack down on corruption and make a dent in the culture of impunity, ${ }^{57}$ many believed that corruption did not wane during the CTG but simply changed hands and nature. This was manifest in the manner in which anti-corruption cases were handled, which raised concerns of fairness and equity. By the end of 2008, the much-hyped anti-corruption drive had begun to fizzle out on account of the "aggressive" and often "selective" measures taken by the CTG. ${ }^{58}$ The release of "high profile" politicians including two former Prime Ministers who were in custody for alleged corruption contradicted the CTG's anticorruption stand. ${ }^{59}$ There were instances when a "single Bench of the High Court Division reportedly granted 298 bails in one day, averaging one order per several minutes." ${ }^{\circ 0}$

That the CTG was unable to import qualitative changes in the governance was evident when in 2007, Bangladesh was rated very poorly by the Global Integrity Report. Despite securing a high score of 81 (strong) for its legal framework, Bangladesh scored a mere 47 (very weak) for actual implementation. ${ }^{61}$ The overall score for Bangladesh in 2007 was 64 (weak). ${ }^{62}$ The presence of the military and their direct involvement in government affairs largely eroded the CTG's profile. Amnesty International noted with concern the role of the armed forces in a range of functions with no clear rules of accountability and observed that the anti-corruption and

$56 \quad I d$. at 17.

57 Ain o Salish Kendra, Human Rights in Bangladesh 2007, at 4 (Sara Hossain \& Dina M. Siddiqi eds., 2008).

$58 \quad I d$.

$59 \quad$ Id.

60 Ain O Salish Kendra, Human Rights In Bangladesh 2008: Dashed Hopes, Receding Horizons, New Frontiers (2008), http://www.askbd.org/web/wpcontent/uploads/2009/01/human_rth_rpt.pdf.

61 Global Integrity Report 2007, Global Integrity, https://www.globalintegrity. org/research/reports/global-integrity-report-2007.

Id. 
anti-crime drives of the CTG were motivated and used to bring political parties to heel. ${ }^{63}$

Notwithstanding the criticisms, the anti-corruption initiatives taken by the CTG may have had some positive impact as evident from Bangladesh's improved ranking in the CPI in the years immediately following the CTG regime. In 2006, 2007, 2008 and 2009, Bangladesh was ranked at number $3,7,10$ and 13 , respectively, from the bottom. ${ }^{64}$

The newly elected political government, which assumed power in 2009, approved many of the laws that had been adopted by the CTG to ensure human rights and good governance. ${ }^{65}$ Yet, the CPI rankings have been demonstrating an unstable trend. For example, in 2010, Bangladesh's ranking in the CPI slid to $12^{\text {th }}$ from the bottom and rose again to $13^{\text {th }}$ in 2011 and $2012 .{ }^{66}$ Bangladesh's ranking improved further when it was placed $16^{\text {th }}$ from the bottom in 2013, three steps higher than that in 2011 and $2012 .{ }^{67}$ Bangladesh's score moved downward by two points, scoring 25 on a scale of $0-100$ in 2014 , and ranked $145^{\text {th }}$ from the top and $14^{\text {th }}$ from below in a list of 175 countries, indicating that corruption continues to be a major threat. ${ }^{68}$ In 2015, Bangladesh again scored 25 points on a scale of 0-100

63 See One Year On: Human Rights in Bangladesh Under the State of Emergency, Amnesty International (Jan. 10, 2008, 00:00 AM), https://www.amnesty. org/en/press-releases/2008/01/one-year-human-rights-bangladesh-under-stateemergency-20080110.

64 Iftekharuzzaman, Bangladesh in CPI 2013, Transparency International BANGladesh (Dec. 4, 2013, 23:05 PM), https://www.ti-bangladesh.org/beta3/ index.php/en/articles/85-articles/3904-bangladesh-in-cpi-2013.html.

65 It may be noted that the government led by the Awami League began to seriously lobby against the system of interim caretaker government system referring to various miscarriages of rule of law and governance committed by the past caretaker government. Amidst much criticism and controversy, the Parliament passed the 15th amendment to the Bangladesh Constitution, which brought a number of changes including the abolition of the caretaker government.

66 Iftekharuzzaman, supra note 64.

$67 \quad I d$.

68 Iftekharuzzaman, Corruption Perceptions Index 2015, Transparency INTERNATIONAL BANGLADESH (Jan. 27, 2016), https://www.ti-bangladesh.org/ beta3/images/2016/ppt_tir_cpi-2015_16_en.pdf. 
and ranked $139^{\text {th }}$ from the top and $13^{\text {th }}$ from below. ${ }^{69}$ Bangladesh's score has been consistently lower than the global average score of 43 , and among the South Asian countries, Bangladesh's position remained $2^{\text {nd }}$ lowest in both rank and score, ahead only of Afghanistan. ${ }^{70}$

\section{B. Anti-Corruption Measures Taken by the Government}

Bangladesh has taken some noteworthy measures aimed at reducing corruption and promoting good governance. The most significant among these are the enactment of a number of laws and the adoption of the National Integrity Strategy. The laws include The Anti-Corruption Commission Act 2004, The Public Procurement Act 2006, and Public Procurement Rules 2008, The Prevention of Money Laundering Act 2009, The Right to Information Act 2009, The Public Finance and Budget Management Act 2009, The National Human Rights Commission Act 2009, The Chartered Secretaries Act, 2010, The Disclosure of Public Interest Information (Protection) Act 2011 and Rules 2016 (which is basically a whistle-blowers' protection law), The Prevention of Money Laundering Act 2012, and The Competition Act 2012. A new Audit Act is in the offing. All of these laws have direct or indirect implications for the fight against corruption.

The Government of Bangladesh adopted the National Integrity Strategy (NIS) in 2012.71 "The NIS has a comprehensive set of goals, strategies and action plans aimed at increasing the level of independence, accountability, efficiency, transparency and effectiveness of the state and non-state institutions to improve governance and reduce corruption in a holistic manner."72 In order to implement the NIS, a National Integrity Implementation Unit (NIIU), National Integrity Advisory Council (NIAC) and Executive Committee of the National Integrity Advisory Council (ECNIAC) have

69 Id.

$70 \quad I d$.

71 Gov't of the People’s Republic of Bangl. Cabinet Div., An Independent Review of the National Integrity Strategy 2 (May 2013), http:// cabinet.portal.gov.bd/sites/default/files/files/cabinet.portal.gov.bd/ publications/90749cbc_ee7d_4a08_9acc_ce795235dc6e/CD_SPEC_GOVT_ POLIC_bn_2_210.pdf.

72 Id. 20. 
been formed; additionally, "Ethics Committees" have been set up in every ministry or department of the government for internalising the core principles promoted by the NIS. ${ }^{73}$ The establishment of the Human Rights Commission and the Information Commission in 2009 for the promotion and protection of human rights and right to information is yet another example of the government's willingness to live up to its commitment to good governance. The use of Citizen's Charters in government offices and major service delivery outlets is an indicator of proactive disclosure of available public services citizens.

Efforts have been invested to strengthen the capacity of the police force to render effective, user-friendly services and pro-people services. Under the Police Reform Programme (PRP), the police publicly discloses its strategic plan, annual reports, work plans, and progress reports on its website. Besides, "performance data collected is also reported publicly." 74 The introduction of e-procurement by public agencies has reduced the scope of corruption and other irregularities by "improving the transparency and integrity in public service such as tendering, sourcing, ordering, and auctioning."75

Despite the encouraging developments, Bangladesh continues to face challenges in effective implementation of the UNCAC. The government's lack of political will to deliver on UNCAC commitments is exacerbated by partisan political influence in decision-making processes of key institutions of accountability, e.g. the executive, legislative, and judiciary, provision for "whitening black money" (legalising illicit funds), and a culture

$73 \quad$ Id. 99.

74 Norad, Joint Evaluation of Support to Anti-Corruption Efforts: Bangladesh County Report 39 (2011), https://www.oecd.org/countries/ tanzania/48912863.pdf.

75 Arjun Neupane et al., Role of the Public E-Procurement Technology to Reduce Corruption in Government Procurement, Proceedings of The 5TH International Public Procurement Conference 304, 310 (2012). 
of impunity that together undermine the value of the anti-corruption initiatives measures.

\section{CORRUPTION AND GOOD GOVERNANCE: CONCEPTUAL ISSUES}

Given the complexities that typify the phenomenon, there is no one definition of corruption. Consequently, corruption has been defined varyingly, depending on the context and type. According to Oxford Advanced Learner's Dictionary, the literal meaning of corruption is: "dishonest or illegal behaviour, especially of people in authority;" and the corrupt are "(people) willing to do dishonest or illegal things in return for money or to get an advantage." 76 In the legal context, corruption implies a "wrongful design to acquire or cause some pecuniary or other advantage." 77 Moreover, American courts ${ }^{78}$ have referred to corruption as an "[i]llegality; a vicious and fraudulent intention to evade the prohibitions of the law. The act of an official or fiduciary person who unlawfully and wrongfully uses his station or character to procure some benefit for himself or for another person, contrary to duty and the rights of others." 79

The approaches taken by different organisations in defining corruption are likewise diverse. One of the United Nations Development Programme (UNDP) discussion papers on corruption and good governance observes, "corruption is a symptom of something gone wrong in the management of the state." ${ }^{\circ 0}$ This definition essentially views corruption from the perspective of governance failure. In like manner, the World Bank defines

76 Corruption, Oxford Learner's Dictionary, http://www. oxfordlearnersdictionaries.com/definition/english/ corruption?q=corruption.

77 Corruption, US LegaL, http://definitions.uslegal.com/c/corruption.

78 U.S. v. Johnson, 20 F. 682, 683 (C.C.S.D. Ga. 1885); State v. Ragsdale, 59 Mo. App. 590, 603 (1894); Wight v. Rindskopf, 43 Wis. 344, 351 (1877); Worsham v. Murchison, 66 Ga. 715, 719 (1881); U.S. v. Edwards, 43 F. 67, 67 (C.C.S.D. Ala. 1890).

79 Corruption, The LAw Dictionary, http://thelawdictionary.org/corruption/ (emphasis added).

80 Mgmt. Dev. and Governance Div. Bureau for Policy and Programme Support United Nations Dev. Programme, Corruption and Good Governance: Discussion Paper 3, at vii (1997) [hereinafter Corruption AND Good Governance]. 
corruption as "the abuse of public office for private gain." covers "various forms of interaction between public sector officials and other agents," 82 but precludes corruption among private sector actors. Transparency International goes a step beyond and defines corruption as "the misuse of entrusted power for private gain." ${ }^{83}$ This definition recognises that corruption can also occur amongst both public and private sector actors. TIB, an accredited chapter of Transparency International and the focal point of this paper, defines corruption as "abuse of power for personal benefits" 84 - TIB believes that, power need not always be "entrusted" and therefore has chosen to drop the term from its definition. TIB also recognises that gains from corruption can be purely "personal" as opposed to "private" - the latter is often interpreted to refer to group interest. "Power" is used here in economic, social or political terms in the public as well as the private sector.

The diversity in the definitions of corruption is an indicator of the many forms through which corruption may occur. In its narrowest sense, bribery is recognised as the most common form of corruption. "In its wider sense however, corruption refers to bribery, extortion, fraud, cartels, abuse of power, embezzlement, and money laundering - activities that will normally constitute criminal offences in most jurisdictions although the precise definition of the offence may differ." ${ }^{15}$ Other forms include, but are not limited to, fraud, collusion, kickbacks, state capture, facilitation payments, favoritism, gift giving, nepotism, clienteles, conflict of interest and patronage. Indeed, the forms in which corruption occur are guided by

81 Odd-Helge Fjeldstad \& Jan Isaksen, Background Paper to Public Sector Reform: What Works and Why? An IEG Evaluation of World Bank Support, AnTICorruption Reforms: Challenges, Effects and Limits of World Bank Support 5 (2008), http://www.cmi.no/publications/file/3134-anti-corruptionreforms-challenges. pdf.

$82 \quad I d$

83 FAQs on Corruption, TrANSPARENCY INTERnATIONAL, http://www.transparency. org/whoweare/organisation/faqs_on_corruption.

84 The Context, Transparency International Bangladesh, http://www.tibangladesh.org/beta3/index.php/en/about-us/the-context.

85 Corruption Information: What is Corruption, Global Infrastructure AntiCorruption Centre, http:// www.giaccentre.org/what_is_corruption.php (last updated Nov. 6, 2014). 
certain key elements, for example, "the participants involved in the corrupt act, the types of norms the act violates, the nature of the transaction, the broader context within which the act occurs and the purpose, outcome or motive of the act." ${ }^{86}$ As Doig and Riley point out:

Corruption is [sic] infinitely varied in its character in [terms of] regimes, institutions and groups across developing economies and is often subject to differing approaches and attention depending on its political significance or its societal impact; for example, 'grand' or high-level corruption versus low-level corruption; judicial, administrative and legislative corruption; or corruption in various public services. ${ }^{87}$

While it is important to distinguish between these factors for a better understanding of corruption, understanding the relationship amongst the different classes of corruption, "their determinants and their consequences continues to confront both theoretical and methodological challenges." 88 Despite the numerous typologies of corruption, there is still no universally acceptable tool to measure the different classes of corruption. ${ }^{89}$ To date, Transparency International's Corruption Perception Index operates as the standardised measure for exploring the level of corruption in countries across the globe. ${ }^{90}$ This method, however, is debated on account of the fact that it is perception-based and one-dimensional as it does not differentiate amongst different forms of corruption. ${ }^{91}$

It is important to recognise that good governance is fundamental to fighting corruption in key sectors and institutions. In essence, the UN General Assembly resolution 51/59, passed on 12 December 1996 at the $82^{\text {nd }}$ Plenary Meeting, set the ground for recognising corruption prevention as an integral part of governance reform initiatives. ${ }^{92}$ Resolution $51 / 59$ states that corruption may "endanger the stability and security of societies, undermine the values of democracy and morality and jeopardize social, eco-

86 Stephen D. Morris, Forms of Corruption, 9(2) CESifo DICE Report 10, 10 (2011).

87 Doig \& Riley, supra note 3, at 34.

88 Morris, supra note 86, at 13.

89 Id.

$90 \quad I d$.

$91 \quad I d$.

92 See G.A. Res. 51/59, 1 (Dec. 12, 1996). 
nomic and political development." ${ }^{93}$ It underlined the International Code of Conduct for Public Officials, which states that "the ultimate loyalty of public officials shall be to the public interests of their country as expressed through the democratic institutions of government" and shall also "ensure that they perform their duties and functions efficiently, effectively and with integrity, in accordance with laws or administrative policies," without discrimination against any group or individual, or without abusing the power and authority vested in them..$^{94}$

While governance has been defined varyingly, involving context specific indicators, the most appropriate definition in the context of this paper would be:

$[\mathrm{H}]$ ow democracy functions - how citizens participate in society; how they are represented in government through elections; how they participate in decision-making; how checks and balances protect individuals from state power; and how local, regional, developed governments provide greater opportunities for the state to respond to the needs of the citizens. ${ }^{95}$

Put simply, governance essentially "comprises of mechanisms, processes and institutions through which citizens articulate their interests, exercise their legal rights, meet their obligations and mediate their differences." ${ }^{\prime 96}$ As such, "governance includes the performance of state institutions, as well as interactions among the government, the private business sector and civil society, including non-profit organisations and volunteer groups." ${ }^{97}$

It therefore follows that "governance" is simply not about structured organs of a state. More significantly, it is about the quality of governance, which expresses itself through traits of accountability, transparency,

93 Id.

$94 \quad$ Id. 99 21-23.

95 Maria Dakolias, Are We There Yet? Measuring Success of Constitutional Reform, 39 Vanderbilt Journal of Transnational Law 1117, 1134-35 (2006).

96 C. Raj Kumar, Corruption in Japan-Institutionalizing the Right to Information, Transparency and the Right to Corruption-Free Governance, 10 New England Journal of International \& Comparative LaW 1, 10 (2004).

97 Corruption and Good Governance, supra note 80, at xii. 
integrity, independence, efficiency, responsiveness, participation, rule of law, equity and justice. The main requisites for good governance include:

(i) political legitimacy for the state through democratic elections and transfer of power, and an effective political opposition and representative government; (ii) accountability and transparency in the sharing of information; (iii) separation of powers; (iv) effective internal and external audit; (v) effective means of combating corruption and nepotism; (vi) competence of public servants; (vii) impartial and accessible justice systems; and (viii) the absence of arbitrary government power. ${ }^{98}$

"Since the attributes of good governance are the outcome of the institutional behaviour of various organs, any analysis of the qualitative aspects of good governance has to cover the functions of all the organs in different contexts." ${ }^{99}$ It is believed that democratic governance is crucial for protecting rights of citizens to the extent they can hold the government accountable for its policies, corruption and abuse of power, challenge inequities of autocratic regimes, deter criminal negligence by the government and demand rule of law enforced with fairness and justice. These principles essentially engender a society in which people are free to make choices, are free from poverty, deprivation, fear and violence, and are free to set priorities that ensure equity, justice and fair play.

\section{A. Causes, Costs and Effects of Corruption}

“The causes of corruption are always contextual, rooted in a country's policies, bureaucratic traditions, political development, and social history." 100 Nevertheless, "corruption perceivably flourishes when institutions of accountability have weak governance and lack integrity." ${ }^{101}$ However, it is

98 Doig \& Riley, supra note 3, at 46.

99 Hasnat Abdul Hye, Good Governance: A Social Contract for the New Millennium, Governance: South Asian Perspectives 7 (2000).

100 The World Bank, Helping Countries Combat Corruption: The Role of the WORLD BANK 12 (1997), http://wwwl.worldbank.org/publicsector/anticorrupt/ corruptn/corrptn.pdf.

101 Salahuddin M. Aminuzzaman \& Sumaiya Khair, National Integrity System Assessment Bangladesh 29 (2014), http://www.ti-bangladesh.org/beta3/ images/2014/fr_nis_NICSA_14_en.pdf. 
acknowledged that weak governance alone does not cause corruption, as there are other factors that also contribute to the phenomenon. Chr. Michelsen Institute (CMI), a development research institute, identifies four conditions that facilitate corruption:

1. Imperatives and incentives that encourage someone to engage in corrupt transactions, for example, low salaries of public officials, cultural norms that encourage favouritism and patronisation and political pressure, to name a few..$^{102}$

2. Availability of multiple opportunities for personal enrichment, for example, economic environments that are more conducive to corruption, in particular mineral and oil rich environments and discretionary powers over the allocation of public resources. ${ }^{103}$

3. Access to and control over the means of corruption, for example, control over administrative processes, such as tendering or having access to offshore accounts and the techniques of money laundering. ${ }^{104}$

4. Limited risks of exposure and punishment, for example, lack of policing, detection and prosecution, weak internal controls, such as financial management, auditing, and human resource systems, controlled media and civil society. ${ }^{105}$

"In Bangladesh, the impact of corruption is often manifested through political intolerance, lack of accountability and transparency, low level of democratic culture, absence of consultation, dialogue and participation, rent seeking and patronage." 106 Although "systemic corruption may co-exist with strong economic performance, experience suggests that corruption is one of the most severe impediments to development and

\footnotetext{
102 The Basics of Anti-Corruption, U4 Anti-Corruption Resource Centre, http:// www.u4.no/articles/the-basics-of-anti-corruption.

103 Id.

104 Id.

$105 \mathrm{Id}$.

106 Aminuzzaman \& Khair, supra note 101, at 29.
} 
growth in emerging and transition[ing] economies." 107 According to the CMI, this is because:

[C]itizens are compelled to pay for services that should be free; state budgets are pillaged by corrupt politicians; public spending is distorted as decision-makers focus spending on activities likely to yield large bribes like major public works; foreign investment is stymied as businesses are reluctant to invest in uncertain environments; efforts to tackle climate change can be undermined as bribes are paid to ignore environmental protection rules in the pursuit of quick profits; and economies suffer. ${ }^{108}$

The effect of corruption is multi-dimensional, commonly ranging from social, cultural, political factors to economic factors. Seen holistically, "corruption affects the quality and composition of public investment, thereby restricting access to essential goods, services, assets, and opportunities and ultimately undermining efforts at poverty reduction and human development." ${ }^{109}$ Moreover, corruption is believed to restrict investment, retard economic growth, ruin institutional capacity to provide basic services to citizens and reinforce poverty. Corruption "can significantly affect the efficiency, fairness and legitimacy of state activities."110 "In [the] political sphere, corruption impedes democracy and the rule of law."111 For instance, public sector institutions suffer from an image crisis and lose credibility when, and if, they misuse or abuse their power for private interest or as a result of political influence. ${ }^{112} \mathrm{On}$ a national scale, "[a]cts of bribery, embezzlement, nepotism or state capture" raise "costs of business and undermine clean government,"113 which in turn, "lead[] to [the]

107 The World BANK, supra note 100, at 8.

108 The Basics of Anti-Corruption, supra note 102

109 Haidy Ear-Dupuy \& Olivier Serrat, Fighting Corruption with ICT: Strengthening Civil Society's Role 4 (2014), http://digitalcommons.ilr.cornell. edu/cgi/viewcontent.cgi?article=1413\&context=intl.

110 Susan Rose-Ackerman, The Political Economy of Corruption, in Corruption and The Global Economy 31, 32 (Kimberly Ann Elliot ed., 1996).

111 K. Jeyamohan, Combating the Omnipresence of Corruption, 5 Bonfring International Journal of Industrial Engineering and Management SCIENCE 24, 26 (2015).

112 Id.

113 OECD, Toolkit For Integrity March 2014, at 5 (2014), http://www.oecd.org/ cleangovbiz/CGB-Toolkit-2014.pdf. 
depletion of national wealth."114 In 2000, the World Bank estimated that "if Bangladesh could reduce its corruption level to those prevailing in countries with highest reputation for honest dealing it could add between $2.1 \%$ and $2.9 \%$ to annual per capita GDP growth. This would contribute to a sustainable reduction in poverty." 115 The National Household Survey of 2012 conducted by TIB showed that $63.7 \%$ of the surveyed households experienced corruption in one or the other selected sector of service delivery. 116 "Most important service delivery sectors affecting people's lives such as law enforcement, land administration, justice, health, education and local government," were gravely affected by corruption. ${ }^{117}$ Measured in terms of bribery in the surveyed sectors, cost of corruption in 2010 was estimated at $1.4 \%$ of the Gross Domestic Product (GDP) or $8.7 \%$ of the annual national budget, which rose in 2012 to $2.4 \%$ of the GDP and $13.4 \%$ of the annual national budget. ${ }^{118}$ The overall cost of petty corruption was estimated to be $4.8 \%$ of the average annual household expenditure. ${ }^{119}$ For households with the lowest range of expenditures, the rate of loss is much higher at 5.5\% compared to higher spending households for whom it is $1.3 \% .^{120}$

Corruption impedes human rights and justice by undermining equal treatment by the law and access to justice. As mentioned in the UNCAC 2003, "[c] orruption hurts the poor disproportionately by diverting funds intended for development, undermining a government's ability to provide basic services, feeding inequality and injustice and discouraging foreign

114 Kay H. Farmer, What is Corruption?, A.P.E.S. PorTal (2011), http://apesportal. eva.mpg.de/status/topic/threats/indirect/corruption.

115 Corruption in Bangladesh: Costs and Cures (unpublished manuscript) (on file with The World Bank).

116 See Iftekharuzzaman, Corruption-Good News in a Depressing Context, The DaIly STAR (Dec. 29, 2012, 12:00 AM), http://www.thedailystar.net/news-detail-262981.

117 Id.

118 Id.

119 Id.

120 See Transparency Int'L Bangl., Corruption in Service Sectors: National Household Survey 2012, at 4 (2012), http://www.ti-bangladesh.org/files/ HHSurvey-ExecSum-Eng-fin.pdf. 
aid and investment. [It] is a key element in economic underperformance and a major obstacle to poverty alleviation and development."121

Given that corruption has a distinct bias against the poor and socially excluded groups, such as women, indigenous communities, or minorities, "they are most adversely affected by malpractices in basic human rights in terms of accessing public services like education, health, justice, utilities and personal safety, as well as the delivery of services of standard quality, all of which are subject to unauthorised payments." ${ }^{122}$ Furthermore, corruption leads to violation of civil and political rights as it discriminates in favour of the moneyed and powerful and violates law and policy with impunity.

\section{B. Good Governance and Human Rights: Exploring the Connection}

Anti-corruption conventions do not allude to corruption as a rights violation, just as human rights instruments do not mention corruption. The UNCAC avoids taking a position on the relationship between corruption and human rights, but it does make brief references to distinct issues that are potentially linked to human rights. ${ }^{123}$ For instance, the right to information in relation to the participation of civil-society in anti-corruption measures (Article 13); property ownership rights in relation to money laundering (Article 23), the return and disposal of stolen assets (Article 57); protecting the defendant's due process rights during a corruptionrelated prosecution (Articles 30-32) or extradition (Article 44); ownership rights over frozen assets (Article 31); and "other rights acquired by third parties" (Articles 34 and 55). ${ }^{124}$ From a human rights perspective, corruption leads to not only misappropriation of money or abuse of power

121 Kofi A. Annan, Foreword to The United Nations Convention Against Corruption, U.N. Office of Drugs And Crimes (2004), http://www.unodc.org/documents/ treaties/UNCAC/Publications/Convention/08-50026_E. pdf.

122 Transparency Int'l Bangl., Building Integrity Blocks for Effective CHANGE 2014-2019, at 29 (2014), https://www.ti-bangladesh.org/beta3/ images/2014/project_proposal_bibec_14_en.pdf.

123 See Matthew Murray \& Andrew Spalding, Freedom from Official Corruption as a Human Right, Governance Studies at Brookings, Jan. 2015, at 7, https:// www.brookings.edu/wp-content/uploads/2016/06/Murray-and-Spalding_v06. pdf.

124 Id. 
but also deleterious effects on citizens, which can result in breaches of human rights. ${ }^{125}$ For example, citizens' rights to food, water, education, health and due process are violated when, and if, they have to pay a bribe to access these basic rights. It therefore follows that the concepts of good governance and human rights are mutually reinforcing, both being based on core principles of participation, accountability, transparency and State responsibility. ${ }^{126}$

Inclusion and participation within a human rights framework implies an active, free and meaningful engagement of citizens in development initiatives and/or governance processes. It is said that rights-based participation is about "shifting the frame from assessing the needs of beneficiaries [sic] to foster citizens to recognise and claim their rights and obligationholders to honour their responsibilities." 127 Indeed, participation is often viewed as both a measure to secure sustainable results and a goal in itself, which makes people aware that "they have the right to demand change and social justice." ${ }^{28}$ This is particularly relevant for contexts where the poor and the marginalised are hard to reach or are excluded due to structural impediments and their lack of knowledge.

It is recognised that "participation" is an over-used term, often divested of the requisite political will or even the capacity to translate it into action. While physical participation of citizens in policy development and

125 Zoe Pearson, An International Human Rights Approach to Corruption, in Corruption \& Anti-Corruption 30, 59 (Peter Larmour \& Nick Wolanin eds., 2013).

126 Office of the United Nations High Comm’r for Human Rights, Frequently Asked Questions on a Human Rights-Based Approach to Development Cooperation 10 (2006), http://www.ohchr.org/Documents/Publications/FAQen. pdf.

127 Andrea Cornwall \& Celestine Nyamu-Musembi, Putting the 'Rights-Based Approach' to Development into Perspective, 25 Third World Quarterly 1415, 1424 (2004).

128 Swedish Ministry of Foreign Affairs, Change for Freedom: Policy for Democratic Development and Human Rights in Swedish Development Cooperation, 2010-2014, at 13 (2010), http://www.government.se/49b74d/co ntentassets/91e0ff64644745aea025d1f2928beb1b/change-for-freedom-policyfor-democratic-development-and-human-rights-in-swedish-developmentcooperation-2010-2014. 
implementation might not always be tenable, there are alternative ways of ensuring citizens' inclusion in the said processes. Existing scholarship identify various participation models - instrumental (extracting information from the participants), consultative (creating opportunities for receiving participants' opinions and positions on an issue), engaged (participants directly engaging in negotiation and decision-making) and empowerment (participants developing skills and abilities to influence decision-making and achieve high level of satisfaction of demands). ${ }^{129}$ While no one model may be considered appropriate, there are simple ways of securing citizens' participation. For example, the practice of making public information readily available in simple format and language, ${ }^{130}$ engaging with civil society organisations and using them as a conduit to reach local communities, developing channels for people to engage with service providers or duty bearers and capacitating the latter to hold them accountable for their services; in addition, people's ability to organise freely and to express their opinions freely are but some examples of citizens' participation. ${ }^{131}$

Concepts of accountability and integrity are pivotal to human rights based policy development, just as they are important for good governance. This approach emphasises on establishing a link between human rights "demand and supply sides through the lens of rights holders, duty bearers and citizenship." 132 While international human rights law does not refer directly to the concept of accountability, human rights treaties impose on states, as "duty holders," an obligation to protect the rights of individuals and provide recourse and justice if their rights are violated. States that fail to do so are answerable for any acts or omissions with respect to this duty. ${ }^{133}$

129 See generally Christian Gruenberg \& Victoria Pereyra Iraola, Participation, Transparency and Accountability in Targeted Social Programs: Case Study Handbook (2007).

130 See United Nations Dev. Programme, Mainstreaming Human Rights in Development Policies and Programming: UndP Experiences (2012).

$131 \quad I d$.

132 OeCD \& The World Bank, Integrating Human Rights into Development: Donor Approaches, Experiences, and Challenges 74 (Sebastian Bartsch ed., 2d ed. 2013).

133 Christian Gruenberg, ICHRP, Integrating Human Rights in the AntiCorruption Agenda: Challenges, Possibilities and Opportunities 26 
Against this backdrop, states have an obligation to provide institutional arrangements that allow all persons - including disadvantaged groups access to accountability mechanisms. Similarly, states have an obligation not to block any person's access to such mechanisms. ${ }^{134}$ Corruption by way of bribes to key officials of the state tips the accountability principle in favour of the moneyed and powerful. This practice disproportionately affects disadvantaged groups, such as the poor, women and minorities. While all forms of accountability are important to the integrity and quality of decision-making, the bottom-up, social accountability, whereby the behavior and conduct of public officials are monitored from below by inter alia independent institutions, a free media, and an active civil society perhaps best supplements the human rights framework. ${ }^{135}$

While the term "transparency" does not appear in any of the international human rights instruments, its significance becomes explicit when it is read together with people's right of access to public information. Right of access to information essentially complements the freedom of expression, because information can transform citizens' expressions into informed opinions on public interest issues. ${ }^{136}$ Access to information is also essential for human rights in general because effective access to public information is a pre-condition for enjoying and demanding other civil, political, economic, social and cultural rights, such as the freedom of expression, participation, education and health. ${ }^{137}$ Not only do governments have a duty to respect the right of access to information, but they also have to ensure that mechanisms exist to ensure that it can be exercised in practice. ${ }^{138}$ Moreover, the application of human rights principles plays a key role in making transparency policies more inclusive by guaranteeing access to

(2010).

134 Id.

135 Id.

136 Id. at $16-17$.

$137 \quad$ Id. at 5.

138 See Claude-Reyes v. Chile, Monitoring Compliance with Judgment, Order of the Court, Inter-Am. Ct. H.R. (ser. C) No. 12.108, 7 (Nov. 24, 2008). 
information for all, irrespective of ethnicity, gender, religion, economic and political status.

As observed by the UN Office of the High Commissioner for Human Rights, corruption prevents the Government from taking steps to the maximum of its available resources to progressively realising the rights recognised in the International Covenant on Economic, Social and Cultural Rights; creates discrimination in access to public services in favour of those able to influence the authorities to act in their personal interest, including by offering bribes; and leads to a loss of public support for democratic institutions, when they fail to function in the interests of the society. ${ }^{139}$ The existence of appropriate regulations, procedures and institutions essentially guide the actions of a state, which in turn create an enabling environment for the enjoyment of human rights by citizens. Governments are under a minimum obligation to establish a regulatory and policy framework that ensures access to essential services of acceptable quality without discrimination, and to see to it that no citizen is deprived of such services. ${ }^{140}$

\section{CIVIL SOCIETY AND ITS ROLE IN FIGHTING CORRUPTION}

Civil society is often regarded as a "key player in a meta-system of checks and balances in a polity, a countervailing force to the power of the state." ${ }^{141}$ Increasingly, key actors in international development have begun to recognise civil society as a vital constituent of the broader effort to hold governments accountable for corruption. It is said that civil society is neither organised for power, which is the basic characteristic of a state, nor for profit, which is a key consideration of business organisations; in essence,

139 See generally United Nations Conference on Anti-Corruption Measures, Good Governance and Human Rights, United Nations Human Rights Office of High Commissioner (Nov. 8-9, 2006), http://www.ohchr.org/EN/Issues/ Development/GoodGovernance/Pages/WarsawConferenceDocuments.aspx.

140 Office of the United Nations High Comm'r for Human Rights, supra note 126 , at 11 .

141 Marcia Grimes, The Conditions of Successful Civil Society Involvement in Combating Corruption: A Survey of Case Study Evidence 1 (OoG, Working Paper No. 2008:22, 2008). 
civil society is the sum total of individual and collective initiatives for achieving a desired common public good. ${ }^{142}$

The term "civil society" evokes many meanings in modern times - a mediating realm between the individual and the state, the world of nonprofit associations and philanthropy, the network of international NGOs, social relations of mutual respect, and, many others; common to all of these meanings are two central ideas: pluralism and social benefit. ${ }^{143}$ The World Bank defines civil society as the wide array of non-governmental and nonprofit organisations that have a presence in public life, expressing the interests and values of their members or others, based on ethical, cultural, political, scientific, religious or philanthropic considerations. On the other hand, Fatton defines civil society as the "private sphere of material, cultural and political activities resisting the incursions of the state." ${ }^{144}$ For Osaghae, three key elements are important in the definition or conceptualisation of civil society: autonomy from the state, public character (setting a normative order for the state), and furtherance of a common good. ${ }^{145}$ Osaghae maintains that:

Civil society refers to formal and informal organizations, including social movements, which occupy the nonstate sphere of the public realm and function in one or more of the following ways: articulating and promoting the interests of diverse groups within society with a view to devising ways in which conflicting interests and differences can be accommodated and resolved; defending individual and collective rights as well as popular sovereignty against intrusions by the state and other powerful groups, including foreign interests; mediating relations between state and the larger society; setting the rules or norms governing the state and society, and upholding accountability of those in government; serving as the ultimate check to state power and its abuse, which sometimes leads its constituents

142 Amit Dholakia, Civil Society and the Regeneration of India's Democracy: Potential and Limits, in Towards Freedom in South Asia: Democratization, Peace and Regional Cooperation 87 (V.A. Pai Panandiker \& Rahul Tripathi eds., 2008).

143 Bruce Sievers, What is Civil Society?, Grantmakers in the Arts, http://www. giarts.org/article/what-civil-society.

144 Robert Fatton, Predatory Rule: State and Civil Society in Africa 4-5 (1992).

145 Patrick Ukase \& Bem Audu, The Role of Civil Society in the Fight Against Corruption in Nigeria's Fourth Republic: Problems, Prospects and the Way Forward, 11 European Scientific Journal 171, 174 (2015). 
to seeking to capture state power; serving as the engineroom of private and local capital; and performing shadow state functions. ${ }^{146}$

The key features of successful civil societies that emerge from various definitions can be summarised to include the following: separation from the state and the market; formed by people who have common needs, interests, and values like tolerance, inclusion, cooperation, and equality; and development through a fundamentally endogenous and autonomous process, which cannot easily be controlled from outside.

That civil society has a significant role in fighting corruption has been underpinned by international and regional conventions. Civil society activism against corruption is clearly endorsed by the UNCAC 2003, which states in its Preamble that:

the prevention and eradication of corruption is a responsibility of all States and that they must cooperate with one another, with the support and involvement of individuals and groups outside the public sector, such as civil society, non-governmental organizations and community-based organizations, if their efforts in this area are to be effective[.] ${ }^{147}$

Article 13 of the UNCAC also urges States Parties to:

take appropriate measures, within its means and in accordance with fundamental principles of its domestic law, to promote the active participation of individuals and groups outside the public sector, such as civil society, non-governmental organizations and community-based organizations, in the prevention of and the fight against corruption and to raise public awareness regarding the existence, causes and gravity of and the threat posed by corruption. ${ }^{148}$

Regional conventions take a similar stand. For example, the African Union Convention on Preventing and Combating Corruption (AUCPCC) 2003 provides in Article 12 that parties work with civil society at large to popularise the AUCPCC, ensure and provide for the participation of civil society in the monitoring process and consult civil society in the convention's

146 Eghosa E. Osaghae, Structural Adjustment, Civil Society and National Cohesion in Africa 21 (1998).

147 UNCAC pmbl., opened for signature Dec. 9, 2003, 2349 U.N.T.S. 41 (emphasis added).

148 Id. art. 13 (emphasis added). 
implementation. ${ }^{149}$ Article III(11) of the Organization of American States (OAS) Inter-American Convention Against Corruption 1996 encourages State Parties to consider the applicability of " $[\mathrm{m}]$ echanisms to encourage participation by civil society and non-governmental organizations in efforts to prevent corruption" within their own legal systems. ${ }^{150}$ Similarly, Article 4(1)(i) of the Southern African Development Community (SADC) Protocol Against Corruption 2001 requires parties to adopt mechanisms to encourage participation by the media, civil society, and non-governmental organisations in efforts to prevent corruption. ${ }^{151}$

Whilst the anti-corruption conventions expect non-governmental organizations (NGOs) to play a role in the prevention of and the fight against corruption and in raising public awareness, they do not spell out how these tasks can be performed to achieve maximum impact. Indeed, the omission might have been intentional, owing to the diversity amongst NGOs in terms of size, knowledge of local conditions, capacity, expertise and more importantly, the level of freedom to carry out the activities in the country of operation. ${ }^{152}$ Therefore, quite understandably, methods that work in one context might not necessarily be as effective in another.

Effective engagement of the civil society in the fight against corruption depends on three key factors: (i) the existence of a legal framework that enables civil society organisations (CSOs) to work without political and legal restrictions, (ii) the willingness of the state to engage constructively with the civil society, and (iii) the effective engagement of CSOs in the fight against corruption. ${ }^{153}$ In other words, CSOs must acquire a legal personality through formal registration in accordance with the laws of the land in order to function. However, CSOs that are reliant on public sector funding cannot operate freely, as they may potentially be subjected to pressure from the state; therefore, in order for CSOs to play the role of

149 Indira Carr \& Opi Outhwaite, The Role of Non-Governmental Organizations, (NGOs) in Combating Corruption: Theory and Practice, XLIV Suffolk University LaW ReView 615, 617 (2011).

$150 \quad I d$. at 621.

151 Southern African Development Community, Protocol Against Corruption art. 4(1)(i), Aug. 14, 2001.

152 Carr \& Outhwaite, supra note 149, at 621.

153 The World Bank, supra note 100, at 39. 
an anti-corruption watchdog, they have to be structurally and financially independent from the government.

Government recognition of CSOs' legitimacy and credibility is critical for effective anti-corruption advocacy. Such recognition is manifest in, for example, the openness and responsiveness of the government in its interaction with CSOs, inclusion of CSOs in policy-making processes, and reflection of CSO recommendations in reform initiatives. Indeed, the true success of civil society activism lies in the operational strategies that CSOs use to challenge corruption, such as the generation of anti-corruption knowledge and awareness and the mobilisation of citizens to raise anticorruption demands, promotion of good practices, lobbying, advocacy and monitoring. Additionally, free flow of information, shared spaces for dialogue and collaboration and long-term support and resources ${ }^{154}$ are some of the other vital elements that are essential for strengthening the capacity of civil society actors to sustain their fight against corruption.

In short, civil society is widely recognised as an essential and an increasingly important agent for furthering good governance in many diverse ways - first, by policy analysis and advocacy; second, by monitoring state performance and the action and behavior of public officials; third, by building social capital and enabling citizens to identify and articulate their values, beliefs, civic norms and democratic practices; fourth, by mobilising particular constituencies, particularly the vulnerable and marginalised sections of masses, to participate more fully in politics and public affairs; and fifth, by development work to improve the wellbeing of their own and other communities. ${ }^{155}$ The challenge is to avoid using civil society to help the

154 Office of the United Nations High Comm'r for Human Rights, A Practical Guide for Civil Society: Civil Society Space and the United Nations Human Rights System 9 (2014).

155 Aisha Ghaus-Pasha, Role of Civil Society Organizations in Governance 3 (2004). 
government dodge its responsibilities but rather to enable social mobilisation to induce the government to operate more efficiently and effectively. ${ }^{156}$

\section{A. Civil Society Actors in Bangladesh}

While the political economy in the post-independence era in Bangladesh was primarily dominated by three major urban-based actors, namely, the bureaucracy, the military, and the political leadership, newer elements soon emerged as additional players in what now constitutes "civil society" in the form of organised, autonomous groups trying to influence the state. Civil society in Bangladesh broadly includes everything from local level citizens' initiatives and activist groups to institutionalised, non-government organisations, business associations, academia, and other interest groups.

In common parlance, there is no distinction between NGOs and civil society, as both are known to advance the interest of universal issues (e.g. discrimination), the interests of particular groups (e.g. the poor and marginalised) or humanity at large. The strategies that NGOs adopt vary, dependent on the causes promoted and the local conditions, and range from the confrontational to the collaborative. Diverse both in terms of mandate and function, NGOs are amongst the most visible civil society actors in Bangladesh. It is believed that the NGO sector owes much of its prominence in national anti-corruption efforts to its capacity to pull together substantial analytical resources and international donor support and to effectively communicate with the media. Civil society partnership with the media has led to a notable rise in reporting and coverage of corruption and human rights violations. Undoubtedly, the media rely on civil society for assessments of the scope of corruption, as well as for information on people's perceptions and attitudes - the level of trust achieved between the media and NGOs in the context of anti-corruption critique of governments is an important step toward reinforcing civil society. Likewise, international donors, bilateral agencies and development partners have

156 John M. Ackerman, Rethinking the International Anti-Corruption Agenda: Civil Society, Human Rights and Democracy, 29 American University International LAW Review 293, 333 (2014). 
persistently pushed the agenda for good governance in Bangladesh and have provided significant support to mobilise anti-corruption reforms.

\section{INTRODUCING TIB'S SOCIAL MOVEMENT AGAINST CORRUPTION}

Good governance in Bangladesh has been dogged by corruption, poverty, lack of representation, inequality, discrimination and violence - all of which are elements the rooting out of which require concerted efforts by the government, civil society and the general public. In order to effectively address these elements, there is a need for information that provides citizens, politicians and policy-makers with a common premise from which to engage in informed dialogue and decision-making. This process demands pluralism and respect for difference of opinion, consensus-building techniques that allow citizens to identify and agree on common goals for democratic governance at the local and national level, and transparency and accountability in government activity to ensure that these shared visions are being implemented by public officials. ${ }^{157}$

Recognising that mobilisation of citizens is imperative for inducing change in people's attitudes, behavior and capacity in resisting corruption, TIB has embarked on a social movement against corruption that encompasses the core elements underpinned above. It is generally agreed that social movements are organisations, groups of people, and individuals, who act together to bring about transformation in society. ${ }^{158}$ TIB's idea of anticorruption social movement stems from the recognition that most citizens regard corruption as an integral part of their lives. The real challenge then lies in changing people's attitude and behavior toward corruption, so that they no longer regard corruption as an unavoidable aspect of their life. Indeed, social movements rise and fall as their success depends both on the movements' capacity to mobilise and on the responsiveness of authori-

157 Canadian Foundation for the Americas, Civil Society in the Promotion and Strengthening of Democracy in the Americas: A Vision for the Future 6 (2006), http://pdba.georgetown.edu/Misc/Groups/Conference_Report_ English.pdf.

158 Mary Kaldor, Civil Society and Accountability, 4 Journal of Human Development and Capabilities 5, 12 (2003). 
ties. ${ }^{159}$ While the primary responsibility of tackling corruption essentially lies with the government, TIB recognises that the people are the ultimate repository of power for raising demand for good governance. As a result, public engagement can create a shared responsibility for service delivery and a shared role for enhancing integrity; in particular, the involvement of internal and external stakeholders in the development of anti-corruption initiatives contributes not only to improving public awareness about the importance of integrity standards, but also facilitates its implementation.

TIB works against corruption, not against the government of the day nor any particular public sector department - TIB's task is to create a demand for effective policy reform and institutional change conducive to the reduction in corruption. ${ }^{160}$ As such, TIB has been growing a social movement, which empowers people to take responsibility for tackling the worst excesses of corruption by channelling bottom-up efforts into a positive force for change in Bangladesh. ${ }^{161}$ To this end, TIB has established 45 citizens' volunteer groups, which form the Committees of Concerned Citizens (CCCs) in 45 locations, and 60 Youth Engagement and Support (YES) groups throughout the country to catalyse anti-corruption social movement. ${ }^{162}$

CCCs are groups of non-partisan volunteers from amongst the citizens with high degree of credibility, integrity, social acceptability, and leadership capacity to inform, motivate and mobilise citizens in challenging corruption and promoting transparency and integrity in service delivery at the local levels. ${ }^{163}$ CCC members, at least 30 percent of whom are women, are drawn largely from professional groups such as teachers, lawyers, journal-

159 Id.

160 Colin Knox, Dealing with Sectoral Corruption in Bangladesh: Developing Citizen Involvement, 29 Public Administration and Development 117, 122-23 (2009).

161 Id. at 123.

162 Committees of Concerned Citizens (CCCs), Transparency International BANGLADESH, https://www.ti-bangladesh.org/beta3/index.php/en/about-us/whatwe-do/engaging-people/committee-of-concerned-citizens (last visited Mar. 13, 2017).

163 Transparency Int'l Bangl., BiBEC: Building Integrity Blocks for Effective ChANGe, 2014-2019, at 9 (2014), https://www.ti-bangladesh.org/beta3/ images/2014/project_proposal_bibec_14_en.pdf. 
ists, doctors, social workers and NGO workers. The primary objective of CCCs is to function as community watchdog forums for creating anticorruption awareness, mobilising citizens to take part in anti-corruption initiatives and helping to create accountable governance at local levels. YES groups comprise of young people between the age of 15 to 27, who are attached with CCCs and participate in various programmes, for example, debating competitions, publications, anti-corruption campaigns, cycle rallies, human chains against corruption and cartoon exhibitions. The aim of YES is to instil in young people the core values of volunteerism and prepare them to take the lead in anti-corruption social movement in the future. Members of both CCC and YES are selected on the basis of set criteria. The work of CCC and YES is supplemented by auxiliary groups made up of individuals who do not or no longer qualify for CCC or YES membership, but want to be part of TIB's movement. TIB believes that the leadership skills of CCCs, the energy and exuberance of youth groups and support of the auxiliary members will together contribute to the development of ownership and sustainability of the anti-corruption movement in Bangladesh. ${ }^{164}$

\section{A. Showcasing TIB's Good Practices}

Essentially a research-based advocacy organisation, TIB undertakes activities at local and national levels that "support democratic values and promote pluralism, consensus building and accountability." ${ }^{165}$ TIB works to further good governance through research and policy analysis and advocacy by monitoring performance of key institutions of accountability and service delivery sectors and enabling citizens, including vulnerable and marginalised groups, to raise their voices against corruption and participate in politics and public affairs.

\section{GENERATING EVIDENCE-BASED ANTI-CORRUPTION KNOWLEDGE}

Research provides important insights into corruption trends and their impact on good governance. Accordingly, TIB conducts research at both the local and national levels with the aim of creating knowledge and garnering

$164 I d$. at 10.

165 Canadian Foundation for the Americas, supra note 157, at 6. 
support through public discourses by involving the media, the public and other stakeholders. At the local level, TIB periodically conducts Citizens Report Cards (to determine the quality, satisfaction and accountability in service delivery in key areas, e.g. education, health, local government, land, and climate finance) and national household surveys (to gauge people's experiences of corruption in selected sectors of public service) in addition to other need based or demand driven studies. At the national level, TIB undertakes diagnostic and other studies to identify governance challenges in selected sectors (e.g. health, education, etc.); institutions of accountability (e.g. parliament, judiciary, public administration, law enforcement, election commission, anti-corruption commission, etc.); and gaps inhering in related laws and policies. The findings from TIB's studies, in turn, inform and reinforce TIB's advocacy for and engagement and communication activities with key stakeholders or institutions. With respect to TIB's research methods, TIB follows established principles and techniques of social science research when conducting its studies.

Another aim of TIB's research is to catalyse changes in practices, processes and policies that have a direct bearing on transparency, accountability, integrity, rule of law and effective and responsive governance. Consequently, TIB's research findings are shared through press conferences in the presence of both print and electronic media. This has proved to be an effective medium for mass dissemination of information on corruption and the flagging of irregularities and governance challenges in select institutions. When the media breaks news with TIB's research findings, it attracts substantial reaction from the government and the public. However, TIB tries to off-set such reactions by sharing the research findings with concerned stakeholders and/or institutions for validation before the formal launch of the study. TIB also practices proactive disclosure of salient information pertaining to the concerned research through a comprehensive Frequently Asked Questions (FAQs) sheet at the time of the report release.

\section{RAISING AWARENESS ON INTEGRITY}

Raising awareness on the nature, forms and incidence of corruption is fundamental to corruption prevention. Appropriately, TIB undertakes multidimensional activities to raise awareness against corruption and promote democratic governance. Issue based rallies, cartoon competitions, essay competitions, debates, folk songs, human chains, and youth conventions 
are some of the mediums through which TIB's anti-corruption messages and information are conveyed to different sections of the public. Offering training programmes to different stakeholders (e.g. media, students, etc.) also constitute an important part of TIB's awareness raising initiatives. One of the most successful example of TIB's training programmes is the hands-on orientation of the public on how to fill out an application asking for information in the exercise of the Right to Information law. Observance of special days, for example, International Anti-Corruption Day (9 December) and the Right to Know Day (28 September) are also marked by special programmes. In addition, diverse promotional materials like newsletters, flyers, posters, stickers, festoons, leaflets, and brochures are used for mass dissemination of anti-corruption messages. Social and New Media, including, but not limited to, TV, radio, community and net radio, websites, social networks, documentaries, public service announcements by $\mathrm{TV}$ or radio, or short message services, also form an integral part of TIB's outreach and communication activities.

In addition, TIB makes use of the People's Theatre, which is a successful platform for communicating anti-corruption messages. Performed at the local level, this platform is used to inform the common people about the dimensions, processes of and actors in corruption and implications thereof, while at the same time motivating people to reject and resist corruption. TIB mentors YES volunteers with acting skills to perform on stage, but the volunteers develop scripts based on their own experiences with corruption. The People's Theatre normally hold shows in public spaces schools, hospitals, local government institutions, or market places - and often combine shows with other activities such as Advice and Information Desks (AI-Desks), mothers' gatherings, Face the Public (FtP), or special day observances.

\section{PROMOTING TRANSPARENCY AND ACCOUNTABILITY}

TIB recognises that access to information and transparency are key tools for fighting corruption and ensuring good governance. As such, TIB invests in creating an informed and active citizenry and helping them raise demands for good governance by putting pressure on state institutions to be accountable for and responsive to citizens' needs and priorities. TIB undertakes diverse activities to promote transparency in key service sectors by providing basic information to users in local communities and 
by assisting them to access information where information is not offered proactively. Steered by TIB's youth volunteers, AI-Desks set up in TIB's offices at the local level and satellite AI-Desks set up at schools, hospitals and local government offices provide service recipients with information regarding their rights and entitlements, range of available services and costs thereof, where applicable, and grievance mechanisms so as to help recipients avoid becoming victims of corruption. Building on the experience of AI-Desks, TIB has introduced Advocacy and Legal Advice Centers (ALAC) to provide legal advice and counseling to people who are victims or witnesses of corruption. ALACs functions by receiving complaints of corruption from victims and witnesses of corruption, scrutinising the complaints and imparting advice on the basis of merit. ALAC also makes referrals to legal aid and anti-corruption agencies.

TIB popularises the Right to Information (RTI) law and the Protection of Whistleblowers law through RTI Fairs organised every year to mark the Right to Know Day on 28 September. Participants at the RTI Fair include both government and non-government agencies that showcase their work, including the services and/or support they offer. These RTI Fairs open up opportunities for interaction between service providers and service recipients in a conducive environment. Demand for RTI Fairs has risen since it was first introduced and there is a marked rise in the interest of government agencies to participate in these fairs.

The government is increasingly working with TIB to deliver "targeted" transparency, i.e. the increased availability of and access to socially useful and focused information to the public. This is evident from the practice by institutions to post relevant information on Information Boards and Citizens' Charters for public consumption. Also, information can be made available on processes that are vulnerable to corruption in order to enable public scrutiny, e.g. e-procurement, which enables all stakeholders to scrutinise the contract management or amendments to the contract.

\section{ADVANCING PARTICIPATORY GOVERNANCE}

Participatory governance is a means of deterring corruption by increasing transparency and public oversight. Participatory accountability paves the way for citizens' continuous involvement in policy discourse, formulation and implementation to reduce the discretionary power of public officials. In addition, participatory accountability increases the transparency and 
accountability of public officials and/or service providers. Three simple examples from TIB's work to illustrate this increasing transparency. "Choose the Right Candidate" is an initiative that helps citizens make informed decisions regarding who to vote into office in both local and national elections. TIB introduces the aspiring candidates to the public in an open forum and provides background information on each of the candidates. Aspiring candidates are then invited to the stage to explain to the public why they should vote for him/her and what s/he plans to do if voted into office. This forum gives voters the opportunity to interact with aspiring political candidates up front and to form an opinion about each candidate. Moreover, this activity paves the way for unseating corrupt political leaders from elections. FtP is another effective social accountability tool used by TIB to help citizens hold public representatives accountable. Organised in collaboration with local government representatives, FtP brings public representatives, government officials and other service providers face-toface with local communities. This process enables people to directly ask questions to public representatives, government officials or service providers with respect to the commitments they made as well as the content and quality of the services rendered by the elected institution. Depending on the institution, FtPs vary in modes, processes and participation; for example, in schools, mothers are the key participants in the for um called "Mothers' Gathering" where they hold school authorities and school management committees accountable for the quality of education and related services, whereas in the local government body, the stakeholders who participate are primarily members of the general public. ${ }^{166}$

The "Integrity Pledge" (IP) is yet another social accountability process introduced by TIB to promote participatory and accountable governance at the level of service delivery by voluntary engagement of local level public representatives, officials, and service providers with the service recipients and other citizens to promote transparency and accountability at the delivery of services in vital sectors such as education, health, land, and local government. ${ }^{167}$ The IP involves a written but a legally non-binding voluntary

166 Transparency Int'l Bangl., Integrity Pledge: Participatory Governance Through Social Accountability, 4 (2012), http://www.ti-bangladesh.org/ beta3/images/max_file/pub_Booklet_ccc-yes_IP_August\%2012.pdf.

167 Id. at 3. 
commitment signed by concerned stakeholders - public representatives, officials, and other service providers, service recipients, and citizens' committees - where all parties pledge to work together and help each other to:

\begin{abstract}
prevent and control abuse of power for private gain; eliminate all forms of unauthorized payments, including bribery for services rendered; ensure and promote participation of service recipients in decisions that affect the content and quality of services provided; ensure transparency in public contracts and in implementing work under such contracts; and promote disclosure and transparency to ensure accountability in all related actions. ${ }^{168}$
\end{abstract}

Involving the people as stakeholders - in design, delivery, monitoring, and assessment of the quality of services - effectively reinforces and strengthens the conventional accountability systems. This approach treats the people as proactive stakeholders rather than as simple beneficiaries or service recipients, so that their voices and demands are counted. ${ }^{169}$

\title{
V. SUSTAINED ADVOCACY FOR GOOD GOVERNANCE
}

Another important role played by TIB is its sustained advocacy in support of anti-corruption efforts at both the national and local levels. An activity undertaken under any one programme head often also impacts activities of another programme head. For example, research results are likely to reinforce advocacy and monitoring activities and also serve to raise awareness of anti-corruption issues. TIB's national level advocacy is premised on key findings of its research in select sectors or institutions, which are collated to produce policy briefs containing pragmatic policy recommendations for lobbying with policy makers and actors in governance, creating knowledge and garnering support through public discourses at the local and national levels by involving the media, the public and other stakeholders. TIB believes that no anti-corruption movement can succeed without active support and participation of the government, including the highest political authority. As such, a key method used by TIB to engage with the government is to organise meetings and dialogues with policymakers and senior officials of the government, including ministers and key decision-makers. TIB implements both quiet and public advocacy campaigns to secure necessary political support for the implementation of

$168 I d$.

169 Id. 
its anti-corruption work. For the quiet and judicious advocacy, measures such as direct one-to-one meetings, briefing notes, power-point presentations and focused-group discussions are undertaken with anti-corruption "champions" within the political leadership and the government. As for public advocacy, pressures are created through public statements, press conferences, roundtables, seminars, media op-eds and talk shows to create public opinion in favour of TIB's anti-corruption and reforms initiatives.

Advocacy at the local level is carried out through civic engagement on the basis of TIB's research findings in selected sectors or institutions and other demand-driven issues with the aim of sensitising citizens and concerned authorities about their rights and duties, helping change their mindset and attitudes, and capacitating citizens to challenge and address corruption. Periodic meetings are held with designated authorities of concerned sectors and institutions to update them on CCC's current events and also to follow up on previous events. Engagements amongst different stakeholder groups strengthen anti-corruption efforts as they focus on collaboration rather than confrontation; besides, they help exchange of information about successful strategies, research, and future directions for improvement. ${ }^{170}$

At the national level, TIB has collaborated with the government on many fronts to help improve governance in selected areas. For example, its collaboration with the Ministry of Public Administration has led to the development and successful implementation of a participatory secondgeneration Citizens' Charter in selected public service delivery institutions. Following the publication of a report on Local Government Engineering Department (LGED), the country's lead agency for developing the rural infrastructure, TIB has been assigned by LGED, with support from the Asian Development Bank, to help identify governance and fiduciary risks within LGED and to develop a road map to ensure good governance in its operations. TIB has closely worked with the Cabinet Division in the drafting process of the National Integrity Strategy. It has collaborated with the Bangladesh government in the implementation and review of UNCAC. The Ministry of Law, Justice and Parliamentary Affairs of Bangladesh also supported TIB in producing an independent civil society review report on the status of UNCAC implementation in Bangladesh. In response to a

170 Carr \& Outhwaite, supra note 149, at 624. 
government request, TIB played a pivotal role in drafting a law to assist the Bangladesh government's efforts to improve NGO governance.

\section{B. Impact of TIB's Activities: Some Examples}

A review of TIB's work both at the national and the local level reveals significant outcomes in terms of challenging corruption and driving changes that positively impact citizens, in particular the poor and the marginalised. TIB's interventions in health, education and local government sectors at the local level through CCCs, YES groups and AI-Desks have helped minimise the harassment that ordinary citizens normally had to face earlier in their attempts to seek services from these institutions. In schools for example, TIB's anti-corruption advocacy and communication have contributed to the reduction of illicit payments in schools (examination fees, books), marked improvement in teachers' attendance and performance, increased transparency in the distribution of scholarships, reformation and activation of the School Management Committees, positive change in the outlook, attitude, and response of concerned school authorities, involvement and interest of mothers/guardians in their children's education, distribution of free text books, reduction in school drop-out, and rise in school enrolment. TIB's IP tool and CCC interventions have raised the rank of Alokdia Government Primary School in Modhupur Upazila of Tangail district from C to A. This success inspired other schools in adjoining areas to seek replication of the IP model. The success of Alokdia is prominently featured in a global report by Transparency International: Global Corruption Report: Education. ${ }^{171}$

Similar results are visible in the health sector. For example, doctors who were previously preoccupied with private practice have started to attend their hospital duties on time, patients have begun to raise questions about undue payments, hospital cleanliness and hygiene have improved, authorities have become more supportive of reforms, list of medicines and doctors and nurses on duty have been openly displayed, unauthorised payment for ambulance and other services has reduced, and patient referrals to private clinics have dropped. ${ }^{172}$

TIB's work with the local government has increased transparency and fairness in the distribution of vulnerable group feeding (VGF) and vul-

171 Transparency Int'L Bangl., supra note 163, at 12.

172 Id. 
nerable group development (VGD) cards and has led to the introduction of the practice of open budgets in local government. Local government representatives have been brought face-to-face with the public for responding to questions and demands for democratic and transparent governance. Citizens at the local level have been capacitated to choose local government electoral candidates on the basis of commitment, integrity and honesty. A number of roads in a bad state of disrepair have been fixed; new tube wells have been set up in some areas and the water is now arsenic free. Tax collection has increased and the number of social benefits improved for the disabled, free-fighters, the elderly and widows. Extra money that used to be paid to obtain a trade license has been stopped.

The degree of volunteerism associated with these changes is significant. This and the fact that various developments have contributed to the overall improvement in public sector governance have been aptly captured in the words of an evaluation mission after assessing the work of TIB:

[Impact] areas in significant areas are: increased tax collection which, in turn, allows investment in public services; savings to hospital users on pathology services in hospitals; an increase in the number of patients seen by doctors; a reduction in the fees paid for outdoor tickets in hospitals and reinvestment in welfare funds; availability, transparency and distribution of medicines in hospitals; and an increase in student attendance at primary schools. Given the centrality of these services to the quality of peoples' lives in Bangladesh, these changes represent significant public sector improvements and are important outcomes from the work of CCCs. ${ }^{173}$

At the policy level the impact of TIB's work is manifest in various anticorruption reforms and legislative developments. TIB played a pivotal role in making corruption a punishable offence and in the enactment of The Anti-Corruption Act 2004, The Right to Information Act 2009, The Public Interest Related Information Disclosure (Protection) Act 2011 (whistleblower's protection law). TIB developed a Code of Conduct on Members of the Parliament, which has been placed as a private member's Bill and has been positively considered by the Standing Committee, and is now

173 Colin Knox \& Tahera Yasmin, Transparency International Bangladesh Impact Assessment 20 (2007). 
awaiting enactment. TIB's advocacy campaigns culminated in Bangladesh's accession to UNCAC in 2007. ${ }^{174}$

Findings from TIB's diagnostic studies on key institutions in the national integrity system produce high impact at the policy level. Many recommendations arising from these studies have been implemented in different government institutions, resulting in improved organisational policies and practices contributing to increased accountability, transparency, and better governance. Reforms have taken place inter alia in the Bangladesh Parliament, Bangladesh Election Commission, the Office of the Comptroller General of Audit, Bangladesh Passport and Immigration Office, Public Service Commission, Bangladesh Road Transport Authority (BRTA), and Chittagong Port, following publication of TIB's research findings on these institutions. The government has implemented many of TIB's recommendations on improving governance in the readymade garments industry in the wake of the Rana Plaza tragedy that had resulted in the death and injury of hundreds of garment factory workers. ${ }^{175}$

The most significant example of TIB's work that has had a direct and indirect impact on policy and institutional reform is its contribution to reforming the Anti-Corruption Commission of Bangladesh. Findings of TIB's diagnostic study on the erstwhile Bureau of Anti-Corruption demonstrated the weaknesses and ineffectiveness of this body and the lack of public trust in it. Based on these findings, TIB advocated for a new and impartial anti-graft body and to this end developed a draft law prescribing the modality for the establishment of an independent Anti-Corruption Commission for the consideration of the government. Pursuant to these initiatives the Anti-Corruption Act was enacted in 2004 and the proposed Anti-Corruption Commission (ACC) was set up. However, the ACC was subjected to financial and administrative limits placed by the government. In addition, the selection of the ACC's Commissioners under political limits had eroded public confidence in the ACC's work. Despite its initial

174 Transparency Int'L BAngL., supra note 163, at 15.

175 Id. at 13-14. 
set-backs, through TIB's advocacy, the ACC was reconstituted in February 2007 with much greater capacity and judicial clout. ${ }^{176}$

\section{CONCLUSION: CHALLENGES AND LESSONS}

TIB's activism at the macro level has been very influential in tackling some of the worst cases of institutional corruption and in building relationships with organisations that can drive change (e.g. the ACC); similarly, TIB's social movement on the ground has more immediate impacts on people facing day-to-day corrupt practices as part of their daily lives ${ }^{177}$ Despite the achievements, TIB's journey has been far from easy. Programmatically, it is difficult to produce evidence of tangible impacts of anti-corruption interventions as this often involves entrenched practices and processes which, in turn, are linked to the attitudes and mindset of relevant stakeholders. Any attempt at inducing change in these aspects is usually confronted by a number of factors, principal amongst which are institutional deficits in terms of integrity, resource, capacity, and more importantly, political will. At the same time, years of passive submission to corruption have caused citizens to believe that corruption is a way of life, a norm, and not an exception. In these circumstances, it is difficult to set verifiable indicators of change as good governance involves changes in the mindset and conduct of both actors in governance, as well as that of the citizens. The political context in which TIB works is not hassle-free either. The lack of commitment amongst actors in governance, non-cooperation by concerned authorities or institutions, reactive actions or statements by the government in the wake of TIB's interventions, changes (whether by way of transfer or promotion) in institutional management or arrangement, restricted access to information, and political instability are some of the external risks TIB faces almost on a daily basis.

Notwithstanding, TIB believes that its work is a means to an end and as such, will bring incremental changes within institutions or sectors and amongst stakeholders with which it engages. TIB also recognises that in order for anti-corruption initiatives to work, the initiatives need to be backed by a strong political will of actors in governance. Indeed, TIB's ex-

176 Knox \& YAsmin, supra note 173, at 28-30.

$177 \quad I d$. at 25. 
periences suggest that there are risks and challenges in the anti-corruption movement just as there are opportunities. Fighting corruption is a collective responsibility in which all levels of society and all actors from the government to civil society and communities must be engaged in order to challenge the status quo and build integrity for effective change. ${ }^{178}$ These opportunities and the popular support for TIB's work are key sources of inspiration for TIB to continue its daunting task of mobilising support against corruption in Bangladesh.

178 Joy Saunders, Integrity Action, Is Fighting Corruption a Collective Responsibility? 12 (2014), http://integrityaction.org/sites/default/files/ publication/files/Fighting_Corruption_Paper_r2.pdf. 